\title{
EFEKTIFITAS ARANG SEKAM PADI DAN AMPAS KELAPA KERING DALAM MENURUNKAN KADAR TIMBAL PADA AIR SUMUR
}

\author{
Rila Riskirana, Sri Mulyati, Jubaidi \\ Politeknik Kesehatan Kementerian Kesehatan Bengkulu, Jurusan Kesehatan Lingkungan, \\ Jalan Indragiri Nomor 03 Padang Harapan Kota Bengkulu \\ r.rizkirana@yahoo.co.id
}

\begin{abstract}
Lead $(\mathrm{Pb})$ the heavy metals that are dangerous to humans as causing neurological disorders, impaired kidney function, and disorders of the reproductive system. Rice husk charcoal and dried coconut pulp has a porous surface structure so that it has considerable potential as an absorbent. This study aims to determine paddy rice husk and coconut pulp dried in lowering levels of Lead $(\mathrm{Pb})$ in water wells dug. This is true experiments research by using Pre Post Test. This study did 2 treatments that used rice husk rice and dried coconut pulp in the ratio $25 \mathrm{~g}: 75 \mathrm{~g}$ and $75 \mathrm{~g}: 25 \mathrm{~g}$ with 5 repetitions. To determine differences in decreased levels of $\mathrm{Pb}$ before and after treatment, Paired $\mathrm{T}$ test that shows the value of $p=0.000<\alpha(0.05)$ this means that there is a significant difference in the decrease in lead concentrations in water wells dug before and after treatment.
\end{abstract}

Keyword : Adsorbent, decreased levels of $\mathrm{Pb}$

\begin{abstract}
Abstrak : Timbal $(\mathrm{Pb})$ adalah logam berat yang sangat berbahaya bagi manusia karena menyebabkan gangguan saraf, gangguan fungsi ginjal, dan gangguan pada sistem reproduksi. Arang sekam padi dan ampas kelapa kering memiliki struktur permukaan yang berpori sehingga memiliki potensi cukup besar sebagai zat penyerap. Penelitian ini bertujuan untuk mengetahui media arang sekam padi dan ampas kelapa kering dalam menurunkan kadar Timbal $(\mathrm{Pb})$ pada air sumur gali. Jenis penelitian ini adalah True Eksperimen dengan desain Pre Post Test. Penelitian ini melakukan 2 perlakuan yaitu menggunakan media arang sekam padi dan ampas kelapa kering dengan perbandingan 25 gr : 75 gr dan 75 gr : 25 gr dengan 5 kali pengulangan. Untuk mengetahui perbedaan penurunan kadar $\mathrm{Pb}$ sebelum dan sesudah perlakuan, dilakukan uji T Test Paired yang menunjukkan nilai $p=0.000<\alpha(0,05)$ hal ini berarti ada perbedaan yang bermakna dalam penurunan kadar $\mathrm{Pb}$ pada air sumur gali sebelum dan sesudah perlakuan.
\end{abstract}

Kata Kunci : Zat Penyerap, Penurunan Kadar Pb

Air merupakan kebutuhan sangat vital bagi kehidupan terutama air bersih bagi manusia. Tubuh manusia terdiri dari $70 \%$ air (Orang dewasa). Sekitar 2,50 liter air dalam tubuh manusia harus diganti dengan air yang baru setiap hari. Diperkirakan dari sejumlah air yang harus diganti 1,5 liter berasal dari air minum dan sekitar 1 liter berasal dari bahan makanan yang dikonsumsi. Jumlah air minum yang harus dipenuhi agar dapat mencapai syarat kesehatan adalah 86,4 liter per kapita per hari (WHO, 2011).

Kebutuhan yang pertama bagi terselenggaranya kesehatan yang baik adalah tersedianya air yang memadai dari segi kuantitas dan kualitasnya yaitu memenuhi syarat kebersihan dan keamanan. Selain itu, air bersih harus tersedia secara kontinyu, menarik dan dapat diterima oleh masyarakat agar mendorong masyarakat untuk memakainya. Apabila tidak demikian, masyarakat akan memakai air yang tidak bersih dimana berasal dari sumber yang tidak terjamin kualitas dan penyediaannya (Wardana, 2012).

Sumber Air bersih dapat membantu pemerintah atau masyarakat pada penyiapan air minum. Sumber air minum yang bersih menjadi sumbangan kepada peningkatan kesehatan manusia. Karena itu air minum yang diperlukan telah diatur melalui Peraturan Kementerian Kesehatan Nomor 492 Tahun 2010 yang meliputi beberapa parameter kualitas air. Salah satu diantaranya adalah kandungan logam berat yang dapat berbahaya bagi kesehatan manusia. 
Adanya logam berat pada sarana air bersih seperti sumur gali/sumur bor sangat berbahaya secara langsung terhadap kesehatan manusia. Secara umum diketahui bahwa logam berat merupakan elemen yang berbahaya di permukaan bumi. Menurut Pujiastuti (2008), istilah logam berat adalah logam yang mempunyai berat jenis lebih tinggi dari 5 atau $6 \mathrm{~g} / \mathrm{cm}^{3}$. Logam berat termasuk unsur metaloid yang bersifat bahaya, jumlah seluruhnya \pm 40 jenis.

Pencemar logam berat merupakan pencemar paling berbahaya, walaupun jumlahnya kecil namun mempunyai tingkat keracunan tinggi karena sifatnya yang tidak terdegradasi dalam lingkungan dan mudah terakumulasi dalam jaringan tubuh makhluk hidup. Peristiwa ini menyebabkan keracunan dan bersifat kronis terhadap makhluk hidup, meskipun ada beberapa logam berat yang diperlukan dalam jumlah kecil.

Ketersediaan logam berat di alam dapat berasal dari lingkungan melalui proses alamiah seperti halnya pelapukan bebatuan secara kimia dan geokimia serta dari proses pembusukan oleh makhluk hidup yang mati dan terurai. Ketersediaan logam di alam juga dapat dari aktifitas manusia dari hasil limbah industri logam. Logam juga diperlukan manusia untuk beberapa proses metabolisme dalam jumlah tertentu logam tersebut adalah logam esensial seperti $\mathrm{Zn}, \mathrm{Cu}, \mathrm{Fe}, \mathrm{Co}$, dan Mn. Tetapi jika logam esensial dalam tubuh lebih banyak teresap maka akan menimbulkan efek atau dampak secara langsung ataupun tidak langsung seperti halnya kematian dan kelainan genetik. Sedangkan logam berat non-esensial merupakan logam yang sampai sekarang belum diketahui manfaat atau mungkin logam tersebut bersifat racun yang tinggi dan juga mempengaruhi kerja enzim dalam proses metabolisme manusia seperti $\mathrm{Hg}, \mathrm{Cd}, \mathrm{Pb}, \mathrm{Cu}$.

Hasil pemeriksaan pendahuluan terhadap sampel air sumur gali di Kelurahan Dusun Besar Kota Bengkulu yang dilakukan di Laboratorium Terpadu Poltekkes Kemenkes Bengkulu menunjukkan adanya kadar $\mathrm{Pb}$ sebesar 0,23 mg/l, kadar ini lebih tinggi 23 kali dengan kadar $\mathrm{Pb}$ pada Permenkes ten- tang kualitas air minum Nomor 492/MENKES/PER/VI/2010 dan lebih tinggi 5 kali dibandingkan kadar $\mathrm{Pb}$ pada Permenkes tentang kualitas air bersih Nomor 416/MENKES/PER/IX1990 yaitu 0,05 mg/l.

Berdasarkan data yang didapat dari labkes Kota Bengkulu, menunjukkan bahwa hasil pemeriksaan air sumur bor menghasilkan kadar $\mathrm{Pb}$ tertinggi sebesar $0,09 \mathrm{mg} / \mathrm{l}$ dan terendah $0,07 \mathrm{mg} / \mathrm{l}$. Bila dibandingkan pada standar kualitas air minum dan air bersih nilai tersebut melebihi standar. Hal ini dapat membahayakan kesehatan masyarakat.

Tubuh manusia tidak memerlukan $\mathrm{Pb}$ terutama bagi anak-anak. Di antaranya adalah mempengaruhi fungsi kognitif, kemampuan belajar, memendekkan tinggi badan, penurunan fungsi pendengaran, merusak fungsi organ tubuh, seperti ginjal, sistem syaraf, dan reproduksi, meningkatkan tekanan darah dan mempengaruhi perkembangan otak. Dapat pula menimbulkan anemia dan bagi wanita hamil yang terpajan timbal akan mengenai anak yang disusuinya dan terakumulasi dalam ASI. Pada jaringan atau organ tubuh logam $\mathrm{Pb}$ akan terakumulasi pada tulang. Karena dalam bentuk ion $\mathrm{Pb} 2+$, logam ini mampu menggantikan keberadaan ion $\mathrm{Ca} 2+$ (kalsium) yang terdapat pada jaringan tulang. Disamping itu pada wanita hamil logam $\mathrm{Pb}$ dapat dapat melewati plasenta dan kemudian akan ikut masuk dalam sistem peredaran darah janin dan selanjutnya setelah bayi lahir $\mathrm{Pb}$ akan dikeluarkan bersama air susu. Meskipun jumlah $\mathrm{Pb}$ yang diserap oleh tubuh hanya sedikit ternyata logam $\mathrm{Pb}$ ini sangat berbahaya. Hal itu disebabkan senyawa-senyawa $\mathrm{Pb}$ dapat memberikan efek racun terhadap berbagai macam fungsi organ tubuh (Nurhasni, 2010).

Berdasarkan hasil penelitian Maulidiyah (2010) ampas kelapa dapat menyerap ion logam berat karena memiliki pori dan mengandung polisakarida yaitu selulosa. Selulosa berfungsi sebagai adsorben pada proses adsorpsi ion logam berat karena selulosa yang memiliki situs aktif $(-\mathrm{OH})$ yang dapat mengikat $\mathrm{Cd}$. Kemampuan daya serap adsorpsi tertinggi ampas kelapa terhadap ion $\mathrm{Cd}$ yaitu antara 98,46\% dengan waktu kontak 10 me- 
nit dan nilai $\mathrm{pH}$ 5. Pada penelitian Kohar (2002), perlakuan Jerami dan Sekam dengan $\mathrm{NaOH} 2 \%$ dengan waktu kontak 1 jam menunjukkan aktifitas penyerapan $\mathrm{Pb}$ yang paling tinggi. Sedangkan pada penelitian Pujiastuti (2008) hasil penelitian menunjukkan adsorbsi yang relatif baik pada pemakaian sekam sebanyak 10 gr, waktu kontak 45 menit, dengan prosentase adsorbsi logam $\mathrm{Pb}$ sebesar 95,24\%.

Sekam Padi sebagai limbah pertanian masih memungkinkan untuk dimanfaatkan dengan adanya kandungan bahan-bahan organiknya. Senyawa utama dinding sel sekam padi adalah polisakarida yaitu serat kasar atau selulosa, lignin, dan hemiselulosa yang memiliki gugus hidroksil yang dapat berperan dalam proses adsorbsi (Rosidi, 2011).

Arang sekam padi dan ampas kelapa memiliki kandungan polisakarida dan kandungan organik yang tinggi sehingga sangat baik digunakan sebagai adsorbent pada pengolahan air untuk menurunkan kadar timbal $(\mathrm{Pb})$ pada air.

\section{BAHAN DAN CARA KERJA}

Jenis penelitian yang akan digunakan dalam penelitian ini adalah True Eksperimen (Eksperimen Sesungguhnya). Dengan desain "Pre Post Test" (Notoatmodjo, 2010). Penelitian ini menggunakan arang sekam padi dan ampas kelapa kering sebagai "adsorbent" dalam menurunkan ion logam berat Timbal $(\mathrm{Pb})$ pada air sumur gali. Adapun desain penelitian yang digunakan adalah 2 kelompok perlakuan dengan 5 kali pengulangan. Cara Kerja diawali dengan mempersiapkan semua alat dan bahan yang diperlukan, yaitu membuat arang sekam padi dan membuat ampas kelapa kering dengan cara dijemur di panas matahari sampai benarbenar kering dan tidak berbau, lalu membuat penyaringan sederhana dari botol Aqua 1,5 liter. Penelitian ini menggunakan media arang sekam padi dan ampas kelapa kering sebagai adsorbent dalam menurunkan kadar $\mathrm{Pb}$ dengan perbandingan berat yang berbeda yaitu 25 gr : 75 gr dan 75 gr : 25 gr. Analisis yang digunakan adalah analisis univariat dan bivariat dengan menggunakan $T$ test paired untuk melihat penurunan kadar $\mathrm{Pb}$ pada air sumur gali sebelum dan sesudah perlakuan.

\section{HASIL}

\section{Analisis Univariat}

Air baku yang digunakan pada penelitian ini adalah air yang berasal dari sumur gali yang memiliki kadar $\mathrm{Pb}$ yang cukup tinggi. Kadar $\mathrm{Pb}$ sebelum perlakuan pada sumur gali di Kelurahan Dusun Besar yang digunakan sebagai sampel ditampilkan dalam tabel 1. Berdasarkan tabel 1 tampak bahwa kadar $\mathrm{Pb}$ pada air baku (sumur gali) cukup tinggi yaitu $0,23 \mathrm{mg} / \mathrm{l}$.

Berdasarkan uji laboratorium yang dilakukan di Laboratorium Terpadu Poltekkes Kemenkes Bengkulu dengan menggunakan media arang sekam padi dan ampas kelapa kering sebagai adsorbent dengan variasi berat media yang berbeda terhadap sampel pre test, perlakuan (post test) 1 dan perlakuan (post test) 2 yakni perbandingan arang sekam padi dan ampas kelapa kering $25 \mathrm{gr}$ : $75 \mathrm{gr}$ dan $75 \mathrm{gr}: 25 \mathrm{gr}$, diperoleh hasil penurunan kadar $\mathrm{Pb}$ yang cukup besar.

\section{Penurunan Kadar Pb}

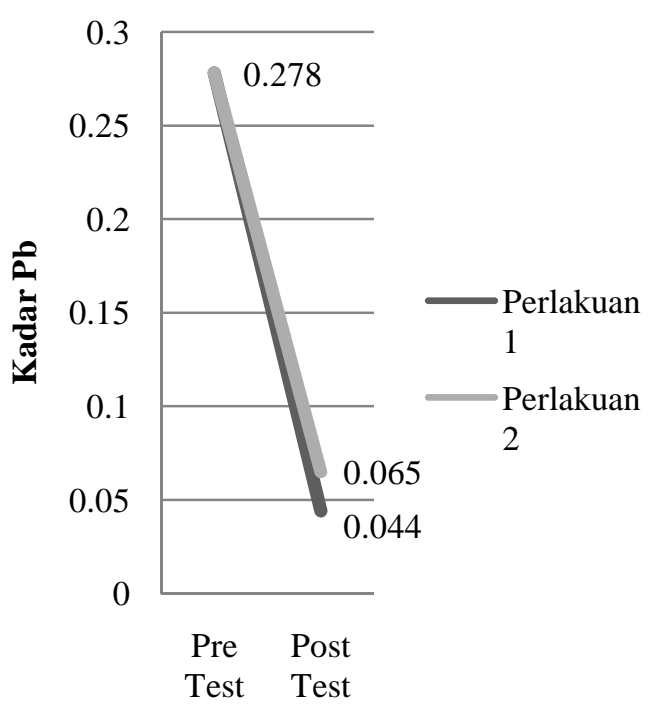

Gambar 1. Rerata Penurunan Kadar Pb Sesudah Perlakuan pada Sumur Gali di Kelurahan Dususn Besar 
Berdasarkan gambar 1 , rerata kadar $\mathrm{Pb}$ sebelum perlakuan (post test) adalah 0,2780 $\mathrm{mg} / \mathrm{l}$. Setelah perlakuan 1 menggunakan arang sekam padi $25 \mathrm{gr}$ : $75 \mathrm{gr}$ ampas kelapa kering adalah $0,0440 \mathrm{mg} / \mathrm{l}$, sedangkan kadar $\mathrm{Pb}$ setelah perlakuan 2 menggunakan arang sekam 75gr : 25gr ampas kelapa kering adalah $0,0650 \mathrm{mg} / \mathrm{l}$.

\section{Analisis Bivariat}

Tabel 1. Rerata Kadar Pb Perlakuan I

\begin{tabular}{cccc}
\hline & $\mathrm{N}$ & $\begin{array}{c}\text { Rata-rata } \\
(\mathrm{mg} / \mathrm{l})\end{array}$ & $\begin{array}{c}\text { Persentase } \\
\text { Penurunan Kadar } \mathrm{Pb}\end{array}$ \\
\hline Sebelum & 5 & 0,2780 & \\
& & & $84,17 \%$ \\
Sesudah & 5 & 0,0440 & \\
\hline
\end{tabular}

Berdasarkan tabel 1 dapat dilihat bahwa nilai rerata kadar $\mathrm{Pb}$ pada sebelum perlakuan adalah $0,2780 \mathrm{mg} / \mathrm{l}$. Setelah perlakuan menggunakan arang sekam padi 25 gr : 75 gr ampas kelapa kering adalah 0,0440 mg/l. Sehingga besarnya penurunan kadar $\mathrm{Pb}$ pada air sumur gali adalah 84,17\%.

Tabel 2. Rerata Kadar Pb Perlakuan II

\begin{tabular}{cccc}
\hline & $\mathrm{N}$ & $\begin{array}{c}\text { Rata-rata } \\
(\mathrm{mg} / \mathrm{l})\end{array}$ & $\begin{array}{c}\text { Persentase } \\
\text { Penurunan Kadar } \\
\mathrm{Pb}\end{array}$ \\
\hline Sebelum & 5 & 0,2780 & \\
Sesudah & 5 & 0,0650 & $76,61 \%$ \\
\hline
\end{tabular}

Berdasarkan tabel 2 dapat dilihat bahwa nilai rerata kadar $\mathrm{Pb}$ pada sebelum perlakuan adalah 0,2780 $\mathrm{mg} / \mathrm{l}$. Setelah perlakuan menggunakan arang sekam padi $75 \mathrm{gr}: 25 \mathrm{gr}$ ampas kelapa kering adalah $0,0650 \mathrm{mg} / \mathrm{l}$. Sehingga besarnya penurunan kadar $\mathrm{Pb}$ pada air sumur gali adalah 76,61\%.

Tabel 3. Hasil Test Sebelum dan Sesudah Perlakuan

\begin{tabular}{ccccc}
\hline & & \multicolumn{2}{c}{$\begin{array}{c}\text { In \% Confidence } \\
\text { Interval of the } \\
\text { Difference }\end{array}$} & \multirow{2}{*}{$\begin{array}{c}\text { Sig. } \\
(2-\end{array}$} \\
\cline { 3 - 4 } & $\mathrm{t}$ & Lower & Upper & \\
\cline { 3 - 4 } $\begin{array}{c}\text { Sebelum- } \\
\text { Sesudah }\end{array}$ & 23.069 & .20113 & .24487 & .000 \\
\hline
\end{tabular}

Berdasarkan tabel 3 dapat dilihat bahwa hasil t-hitung 23,069, perbedaan terendah keduanya 0,20113 , sementara perbedaan ter- tinggi 0,24487 dan nilai signifikansi 0,000 . Dengan nilai signifikansi $0,000<\alpha(0,05)$, maka hipotesis ini menyatakan ada perbedaan yang bermakna dalam penurunan kadar Timbal $(\mathrm{Pb})$ pada air sumur gali sebelum dan sesudah perlakuan dengan menggunakan arang sekam padi dan ampas kelapa kering dengan perbandingan $25 \mathrm{gr}$ : $75 \mathrm{gr}$ dan $75 \mathrm{gr}$ : $25 \mathrm{gr}$ diterima.

\section{PEMBAHASAN}

\section{Kadar Timbal (Pb) Sebelum dan Sesudah Perlakuan}

Berdasarkan tabel 4.1 hasil pemeriksaan kadar $\mathrm{Pb}$ pada air baku yang dijadikan sampel memiliki kadar $\mathrm{Pb}$ yang cukup tinggi yakni $0,23 \mathrm{mg} / \mathrm{l}$. Kadar ini melebihi kadar maksimum yang diperbolehkan oleh Permenkes RI Nomor 416/Menkes/Per/IX1990 Tentang Syarat-syarat dan Pengawasan Kualitas Air Bersih yaitu $0,05 \mathrm{mg} / \mathrm{l}$.

Cukup tingginya kadar $\mathrm{Pb}$ pada air baku karena daerah air baku berada di pinggir jalan dengan kondisi letak yang hanya berjarak \pm 7 meter dari jalan raya, \pm 10 meter dari Danau Dendam, \pm 4 meter dari parit dan \pm 9 meter dari bengkel. Tingginya kadar $\mathrm{Pb}$ juga diakibatkan letak air baku berada di dataran rendah dengan lantai sumur yang banyak retak sehingga kadar $\mathrm{Pb}$ yang dihasilkan dari kendaraan di jalan raya masuk kedalam sumur gali. Timbal masuk dalam ke perairan melalui pengkristalan di udara yang merupakan hasil pembakaran bahan bakar kendaraan bermotor dengan bantuan hujan. Dapat pula sebagai akibat proses korosifikasi bahan mineral akibat hempasan dan angin (Pujiastuti, 2008).

Pengambilan air untuk perlakuan dilakukan sebanyak 5 kali dan dilakukan pada waktu yang berbeda. Hal ini untuk menghindari homogenitas air apabila diambil pada hari yang sama. Sehingga pada penelitian ini peneliti melakukan pengambilan air sebelum perlakuan dengan jarak hari yang berbeda-beda, untuk melihat perbedaan struktur pada air yang dipengaruhi oleh berbagai macam hal seperti cuaca. Apabila turun hujan pada waktu sebelum pengambilan 
air tentu akan mempengaruhi bentuk fisik dan kimia air sehingga wajar apabila pada penelitian ini nilai untuk sebelum perlakuan bervariasi.

Berdasarkan hasil penelitian, didapat bahwa kadar $\mathrm{Pb}$ pada tiap pengulangan berbeda-beda, hal ini karena proses penimbangan arang sekam padi dan ampas kelapa kering yang kurang efektif. Dimana pada penelitian hari pertama dan penelitian hari kedua proses penimbangan menggunakan timbangan analitik, sedangkan pada hari ketiga sampai hari kelima menggunakan timbangan makanan. Perbedaan alat penimbangan ini karena keterbatasan muatan saat proses penimbangan pada timbangan analitik, sehingga pada hari selanjutnya peneliti menggunakan timbangan makanan untuk menimbang arang sekam padi dan ampas kelapa kering. Kurang efektifnya proses penimbangan maka akan mempengaruhi hasil pemeriksaan.

\section{Efektifitas Arang Sekam Padi dan Ampas Kelapa Kering}

Berdasarkan hasil penelitian diketahui bahwa ada perbedaan penurunan kadar $\mathrm{Pb}$ antara sebelum (pre test) dan sesudah perlakuan (post test). Kadar $\mathrm{Pb}$ sebelum perlakuan $=0,2780 \mathrm{mg} / \mathrm{l}$ dan setelah perlakuan $25 \mathrm{gr}: 75 \mathrm{gr}=0,0440 \mathrm{mg} / \mathrm{l}$, sedangkan pada perlakuan $75 \mathrm{gr}: 25 \mathrm{gr}=0,0650 \mathrm{mg} / \mathrm{l}$. Kadar $\mathrm{Pb}$ pada perlakuan $25 \mathrm{gr}$ : 75 gr telah memenuhi syarat kualitas air bersih Permenkes RI Nomor 416/Men-lkes/Per/IX1990 yaitu 0,05 mg/l. Sedangkan kadar $\mathrm{Pb}$ pada perlakuan 75 gr : 25 gr belum memenuhi syarat kuali-tas air bersih Permenkes Republik Indonesia Nomor 416/Menkes/Per/IX1990.

Berdasarkan penelitian ini terlihat bahwa terjadi penurunan kadar $\mathrm{Pb}$ yang efektif yaitu pada perlakuan arang sekam padi 25 gr : 75 gr ampas kelapa kering karena telah memenuhi syarat kualitas air bersih Permenkes RI Nomor 416/Menkes/Per/IX1990.

Penurunan kadar $\mathrm{Pb}$ pada penelitian ini terjadi karena adanya proses adsorbsi oleh media arang sekam padi dan ampas kelapa kering yang memiliki jaringan selulosa se- hingga dapat mengikat ion logam berat seperti timbal (Maulidiyah, 2010).

Menurut Nurhasni (2010) "Adsorbent" merupakan suatu penyerap yang dalam hal ini berupa senyawa karbon, sedangkan " $a d$ sorbent" adalah media yang diserap. Salah satu adsorben yang biasa diterapkan dalam pengolahan air minum (juga air limbah) adalah karbon aktif atau arang aktif. Arang digunakan untuk menghilangkan bau, warna, dan rasa air termasuk ion-ion logam berat, karena merupakan fenomena permukaan maka semakin luas permukaan kontaknya makin tinggilah efisiensi pengolahannya. Syarat ini dapat dipenuhi oleh arang yang sudah diaktifkan sehingga menjadi porous dan kaya saluran kapiler yang belum aktif, ruang kapilernya masih ditutupi oleh pengotor berupa zat organik dan anorganik (Rosidi, 2011).

Adsorbsi adalah suatu proses pemisahan bahan dari campuran gas atau cair. Bahan yang harus dipisahkan ditarik oleh permukaan adsorbent padat dan diikat oleh gayagaya yang bekerja pada permukaan tersebut. Proses adsorbsi terjadi pada permukaan poripori dalam butir adsorbent. Transfer massa logam dari cairan kedalam pori-pori butir adsorbent tersebut akan mengalami prosesproses sebagai berikut: (a) perpindahan massa dari cairan ke permukaan butir, (b) difusi dari permukaan butir kedalam butir melalui pori, (c) perpindahan mas-sa dari cairan dalam pori ke dinding pori, (d) adsorbsi pada dinding pori. Adsorbent alami yang dapat digunakan dalam penurunan kadar logam berat pada air antara lain zeolit, arang aktif, arang sekam padi, ampas teh, kulit kacang, ampas kelapa kering (Nursyamsi, 2010).

Adsorbsi ini digunakan untuk proses penyerapan bahan-bahan tertentu, sehingga air menjadi jernih ka-rena zat-zat didalamnya diikat adsorbent. Cara ini efektif untuk mengurangi warna serta menghilangkan bau dan rasa. Prinsip kerja absorpsi yaitu ion-ion bebas didalam air diserap oleh absorbent (Kusnaedi, 2007).

Penelitian ini sejalan dengan penelitian yang telah dilakukan oleh Pujiastuti (2008) yang berjudul Adsorbsi Logam Timbal Da- 
lam Limbah Elektroplating Dengan Sekam Padi. Dimana hasil penelitiannya menunjukkan bahwa pemakaian arang sekam padi sebanyak 10 gr yang ditambahan larutan $\mathrm{NaOH}$ dengan waktu kontak 45 menit, dapat menyerap logam $\mathrm{Pb}$ sebesar 95,24\%. Sedangkan hasil penelitian yang dilakukan peneliti dengan waktu kontak 1 jam menggunakan perbandingan media arang sekam padi 25 gr : 75 gr ampas kelapa kering dapat menyerap $\mathrm{Pb}$ sebesar $84,17 \%$.

Hasil penyerapan arang sekam padi terhadap logam $\mathrm{Pb}$ sangat tergantung pada waktu proses, dimana semakin lama waktu kontak hasil penyerapan terhadap logam $\mathrm{Pb}$ akan semakin besar atau semakin lama waktu proses sisa $\mathrm{Pb}$ akan semakin menurun. Hal ini karena penyerapan arang sekam padi terhadap logam $\mathrm{Pb}$ merupakan proses fisika yang berjalan pelan. Semakin lama waktu penyerapan berarti proses kontak antara arang sekam padi dengan partikel-partikel logam semakin lama sehingga logam yang terserap akan semakin besar atau logam yang tersisa dalam air akan semakin kecil (Pujiastuti, 2008).

Penelitian ini juga sejalan dengan penelitian yang telah dilakukan oleh Maulidiyah (2010) yang berjudul Pemanfaatan Ampas Kelapa Kering Pada Proses Adsorpsi Ion Logam Berat Cd Dengan Variasi Waktu Kontak dan Ph. Dimana hasil penelitiannya menunjukkan bahwa penggunaan ampas kelapa kering dengan waktu kontak 10 menit dapat menyerap logam berat Cadmium sebesar $98,46 \%$. Sedangkan hasil penelitian yang dilakukan peneliti dengan waktu kontak 1 jam menggunakan perbandingan media arang sekam padi $25 \mathrm{gr}$ : $75 \mathrm{gr}$ ampas kelapa kering dapat menyerap $\mathrm{Pb}$ sebesar 84,17\%.

Ampas kelapa kering dapat menyerap $\mathrm{Pb}$ lebih besar, karena ampas kelapa kering

\section{DAFTAR RUJUKAN}

\section{Gede.2009.Karbon Aktif.}

http://gedehace.blogspot.com/2009/03/adsorpsikarbon-aktif.html. diunduh 27 Desember 2012 pukul 20.30 WIB

Kusnaedi. 2007. Mengolah Air Gambut dan Air Kotor untuk Air Minum. Jakarta: Penerbit Swadaya memiliki struktur permukaan yang berpori dan kandungan kimia berupa selulosa $16 \%$, galaktomannan $61 \%$ dan mannan $21 \%$ sehingga memiliki potensi cukup besar sebagai zat penyerap (Zuhandri, 2012).

Ampas kelapa memiliki kandungan polisakarida yaitu selulosa yang berfungsi sebagai absorben pada proses absorpsi ion logam berat seperti $\mathrm{Pb}$ karena selulosa yang memiliki situs aktif $(-\mathrm{OH})$ yang dapat mengikat ion logam berat $\mathrm{Pb}$. Logam berat memiliki sifat berakumulasi pada suatu jaringan organisme serta sulit terurai menyebabkan tingginya kandungan logam berat pada suatu organisme (Maulidiyah, 2010). Semakin banyak jumlah adsorbent maka konsentrasi larutan $\mathrm{Pb}$ akan semakin kecil, hal ini karena besarnya luas permukaan aktif adsorbent makin bertambah (Sembodo, 2005).

\section{KESIMPULAN}

Kadar $\mathrm{Pb}$ sebelum perlakuan adalah 0,2780 $\mathrm{mg} / \mathrm{l}$, setelah perlakuan menggunakan arang sekam padi 25 gr : 75 gr ampas kelapa kering adalah $0,0440 \mathrm{mg} / \mathrm{l}$ dan perlakuan menggunakan arang sekam padi 75 gr : 25 gr ampas kelapa kering adalah 0,0650 $\mathrm{mg} / \mathrm{l}$. Sehingga penurunan kadar $\mathrm{Pb}$ sebesar $84,17 \%$ dan $76,61 \%$. Media arang sekam padi dan ampas kelapa kering dengan perbandingan 25gr : 75gr lebih efektif dalam menurunkan kadar $\mathrm{Pb}$ pada air sumur gali dibandingkan $75 \mathrm{gr}$ : 25gr.

Peneliti menyarankan kepada masyarakat bahwa air yang mengandung $\mathrm{Pb}$ tinggi bisa digunakan, kecuali untuk dikonsumsi dan bila akan dikonsumsi masyarakat dapat mencari air yang memiliki kadar $\mathrm{Pb}$ rendah dan sebaiknya masyarakat melakukan pemeriksaan pada air baku seperti sumur gali/bor di Laboratorium.

Maulidiyah, V.O. 2010. Pemanfaatan Ampas Kelapa Kering Pada Proses Adsorpsi Ion Logam Berat Cd(Ii) Dengan Variasi Waktu Kontak Dan Ph. Dari http://karyailmiah.um.ac.id/index.php/kimia/article/view/15 889 diunduh tanggal 20 Desember pukul 23.00 WIB 
Notoatmojo, Soekidjo. 2010. Metodologi Penelitian Kesehatan. Jakarta: Rineka Cipta.

Nurhasni, 2010, Penyerapan Ion Logam Cd dan Cr Dalam Air Limbah Menggunakan Sekam Padi. http://journal.uinjkt.ac.id/index.php/valensi/articl e/view/244 diunduh tanggal 31 Januari 2013 pukul 21.31 WIB

Nursyamsi, 2010. Efektifitas Koagulan dan Adsorbent Alami dalam Pengolahan Limbah Cair Elektroplating Tercemar Logam Berat Karsinogenik. Jurnal Teknik Hidraulik, Vol. 2 No. 1, Juni 2011: 1-96. Yogyakarta

Pujiastuti C, 2008. Adsorbsi Logam Timbal Dalam Limbah Elektroplating Dengan Sekam Padi. Pengolahan Sumber Daya Alam Dan Energi Terbarukan. ISSN 1978-0427. 18 Juni 2008. Surabaya,Press Surabaya

Rosidi, Joechiana. 2011. Pemanfaatan Arang Sekam Padi dan Tanah Gambut dalam Menurunkan Kesadahan. Skripsi, Universitas Tadulako. Palu
Sembodo, Bregas. 2005. Isoterm Kesetimbangan Adsorpsi Timbal Pada Abu Sekam Padi. Ekuilibrium Vol. 4 No 2.Desember 2005. Bandung

Wardana. 2012. Sumber dan Faktor Pencemaran Air dari http://caisl.blogspot.com/2012/07/pengertiandam paksumberkomponenfaktor.html diunduh 1 Februari 2013 pukul 22.00 WIB.

WHO, 2011. Pedoman Mutu Air Minum. Jakarta: Penerbit Buku Kedokteran EGC

Zuhandri, 2012. Pengaruh masa ragi dan lama fermentasi terhadap pembentukan etanol dari ampas kelapa. 20 jan 2013 http://zuuhandri.blogspot.com/2012/03/pengaruh -massa-ragi-dan-lama-fermentasi.html 